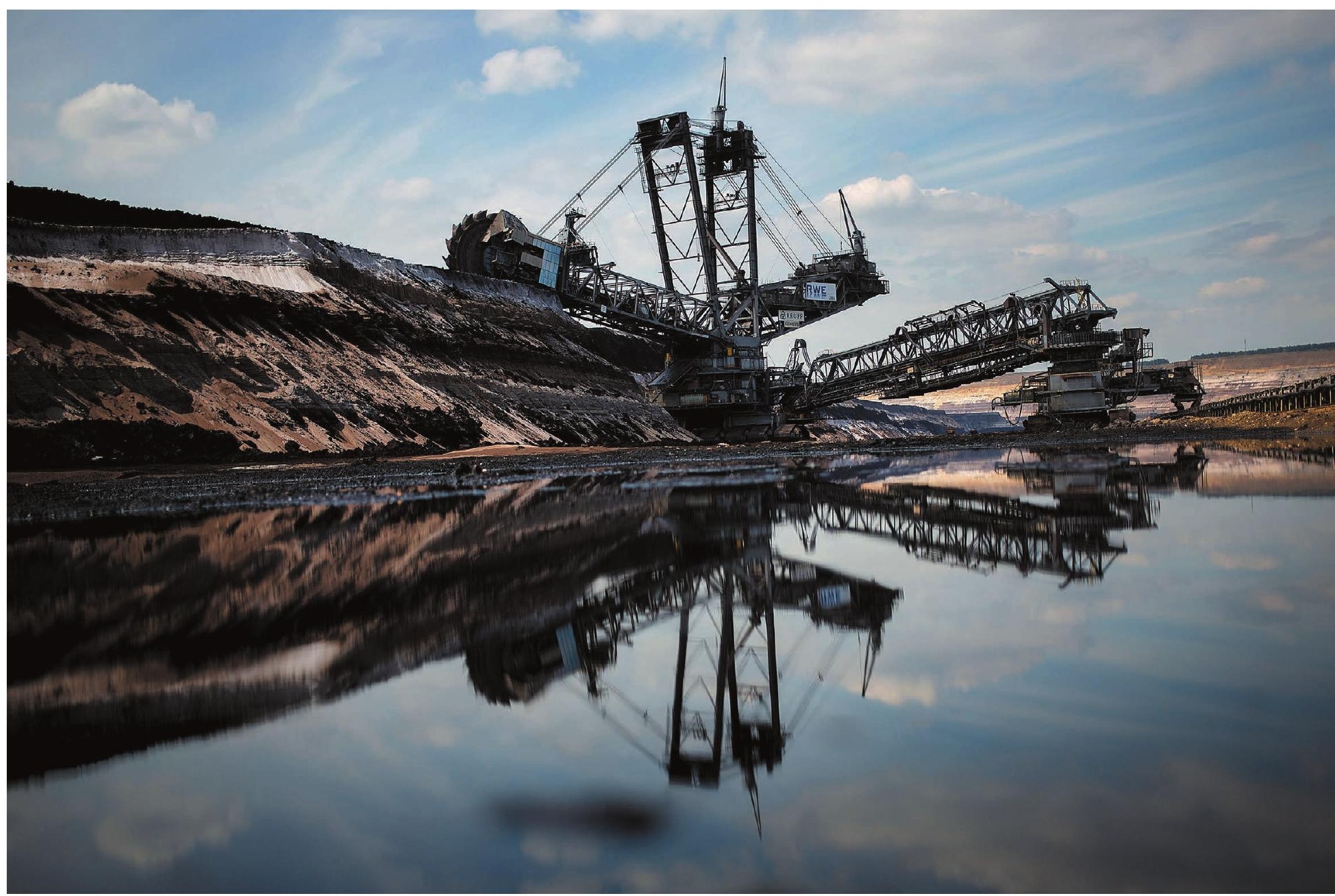

An open-cast coal mine in Germany, where fossil fuels still dominate the energy mix despite the country's ambitions to shift to renewable sources.

\title{
Germany must go back to its low-carbon future
}

Once a world leader in renewables, the nation will miss all of its environmental goals unless the next government realigns its energy policies, warns Claudia Kemfert.

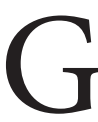
ermany's train to a carbon-free future has been derailed. After introducing feed-in tariffs for renewable energy in 2000, the country became the global leader in wind and solar technologies, to the envy of the world. There was a steep learning curve, but manufacturers, generators and installers gained experience and drove down the costs of clean electricity generation by more than $50 \%$. Companies such as Enercon and Siemens came to dominate wind-turbine technology. Today, Enercon has installed 26,000 windmills and has a market share of $40 \%$ in Germany,
$26 \%$ in Europe and $6.6 \%$ worldwide.

In 2010, the German government built on this success by implementing a bold package of legislation designed to support its low-carbon energy transition (Energiewende). Its ambitious policies sought to shift the nation from fossil fuels to renewable power sources, make buildings and transport more energy efficient, and boost energy-focused research and development (R\&D). By 2050, the intention was for carbon dioxide emissions to be $95 \%$ lower than in 1990, for renewables to provide $80 \%$ of electricity and for energy consumption to be $50 \%$ more efficient than in 2010 (ref. 1).

Unfortunately, progress has stalled. The Energiewende milestones for 2020 are already out of reach ${ }^{2}$. Poor policy choices and lobbying by the fossil-fuels industry mean that Germany will not reduce its greenhousegas emissions by $40 \%$ by 2020 , and so will fail to meet its goals under the Paris agreement to keep global temperature increases well below $2^{\circ} \mathrm{C}$ (ref. 3). At current rates, it will miss all of its interim energy-efficiency targets for 2020, 2030 and 2040.

On 24 September, Germany will elect a new 
government. Rebooting the Energiewende must be one of its top priorities. There is still time to meet the 2050 goals - just.

\section{COUNTERPRODUCTIVE POLICIES}

Coal continues to dominate Germany's energy mix - it is cheap in part because the impacts of its $\mathrm{CO}_{2}$ emissions are not factored into its price. Its use has barely dipped. Because the market favours it, coal provides $43 \%$ of the country's electricity - despite falling profits from coal plants. Even on windy days, coal is burned ${ }^{4}$ and excess wind power is squandered. As a result, Germany's greenhouse-gas emissions increased in 2016; even higher levels are likely in 2017.

Furthermore, an ill-advised switch in 2016 from feed-in tariffs to a tendering system for renewable-energy provision backfired. Competition between companies fell because small firms and energy cooperatives could not compete with the price offers of large competitors. As a result of focusing only on the cost-effectiveness of projects instead of taking a holistic approach, most projects are being built in the windy north of Germany, where turbines keep spinning. This ignores the lack of infrastructure for transmitting power to the south. At least three extra high-voltage grids are required: an enormous, avoidable expense. It makes more sense to spread renewable-energy generation across the country - a decentralized system reduces transmission costs.

Germany has also failed to meet its goal of improving the energy efficiency of buildings by refurbishing $2 \%$ of its stock each year. In 2016 , only $1 \%$ of buildings were improved, because there was not enough financial support for owners to carry out the works.

There is no coherent plan for sustainable transport (see also page 20) - the government did not connect the Energiewende goals to the sector. The recent diesel-vehicleemissions scandal was swept under the carpet, meaning that diesel engines continue to be put on the road. Germany's goal to have 1 million electric cars ${ }^{5}$ by 2020 will be missed by a mile. Today there are around 34,000 electric vehicles on Germany's streets; in 2020, there will be no more than 50,000. The government's subsidy of $€ 4,000$ (US $\$ 4,700$ ) per car is wasted without a wider strategy ${ }^{6}$ to encourage people to travel less or to switch to cleaner forms of transport. No efforts are being made in this area.

Germany has barely increased its energy R\&D spending over the past ten years ${ }^{7}$. In 2015 , it put $0.025 \%$ of its annual gross domestic product (GDP) into energy R\&D, amounting to nearly €863 million. Among countries in the Organisation for Economic Co-operation and Development, only the United Kingdom invests a smaller percentage (see 'Small change'). Germany is pouring money into $\mathrm{R} \& \mathrm{D}$ for technologies that

have a limited future: nuclear energy (which is being phased out by 2022) and carbon capture and storage, the efficacy of which is doubtful.

Germany is meeting its Global Apollo Programme pledge to spend at least $0.02 \%$ of GDP on public R\&D to make renewably sourced electricity less expensive than that from coal by 2025. It is not keeping its other promises. Mission Innovation, a global initiative that aims to double energy $R \& D$ spending in five years ${ }^{8}$, requires the German government to budget $€ 1.2$ billion for research on the energy transition each year. Yet in 2015, the country spent only $€ 640$ million on R\&D in energy efficiency and renewable energy.

\section{ENERGY RENEWAL}

Three priorities can help the next government put Germany back on the Energiewende track.

First, it should phase out coal, ideally by 2030 . This will require deadlines and inducements, which must include effective pricing of $\mathrm{CO}_{2}$ and taxes for fossil fuels. The $€ 57$ billion $^{9}$ in subsidies that harm the environment - including $€ 7$ billion for diesel cars - must be phased out. Energy taxes and charges must be reformed across all sectors, for example to increase the share of renewable energy used for transport and heating, as well as electricity production. Feed-in tariffs should be brought back to revive the flagging renewables market; the current tendering system should be scrapped.

Second, the government should devise a coherent strategy for improving the energy efficiency of buildings and transport. Regulation and financial support would encourage the retrofitting of more buildings. A sustain-

\section{"Germany's} greenhousegas emissions increased in 2016; even higher levels are likely in 2017." able transportation strategy, including a quota for electric vehicles, would encourage people to avoid unnecessary journeys and promote climatefriendly modes of transport and fuel. Cities could encourage bicycles, public transport and car sharing while discouraging private petrol and diesel cars. Germans should take the train rather than flying or driving. Trains produce much less pollution: only $20 \%$ of the greenhousegas emissions per person from aeroplanes and $25 \%$ of the emissions from cars.

Third, there should be more government investment in technological innovation. Doubling the energy R\&D budget is a good start. The returns would be substantial. With each innovation, energy-generation and system costs will fall. Researchers should focus on digital tools to manage energy supply and demand across smart electricity grids,

\section{SMALL CHANGE}

Germany spends less of its gross domestic product (GDP) on energy research and development than all other advanced economies except the United Kingdom.

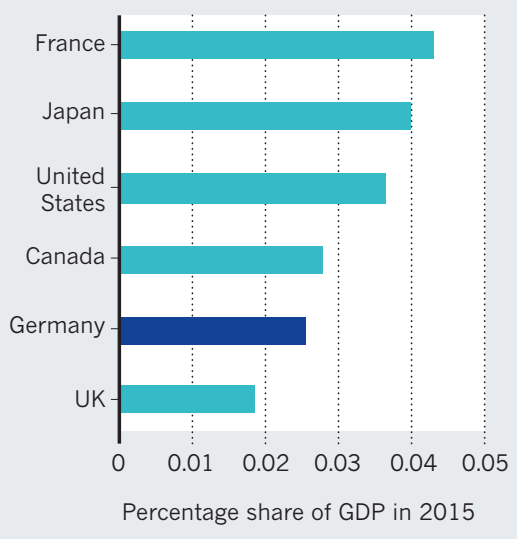

which is vital for variable sources such as the Sun and wind. Focusing on energy storage is crucial so that electrical power harvested in peak periods can be used later or elsewhere, such as for heating and transport. Technologies that convert surplus electricity from renewables into liquid fuels or hydrogen can make fuel for ships and aeroplanes. Better batteries will bring down the costs of electric vehicles and of household production and storage of energy.

The next government would be foolish to squander Germany's leadership in the lowcarbon future. It must take this opportunity to again make Germany a shining example to other countries.

Claudia Kemfert is head of the Energy, Transportation, Environment Department at the German Institute of Economic Research (DIW Berlin) and professor of energy economics and sustainability at the Hertie School of Governance in Berlin, Germany. e-mail:sekretariat-evu@diw.de

1. Bundesministerium für Wirtschaft und Technologie. Energiekonzept der Bundesregierung für eine umweltschonende, zuverlässige und bezahlbare Energieversorgung (BMWi; 2010); available at http://go.nature.com/2g83usq (in German).

2. Kemfert, C. The Battle About Electricity (Murmann, 2013).

3. Figueres, C. et al. Nature 546, 593-595 (2017)

4. Bundesministerium für Wirtschaft und Technologie. Fünfter Monitoring-Bericht "Energie der Zukunft" (BMWi, 2016); available at http:// go.nature.com/2xeebtj (in German).

5. Bundesregierung Regierungsprogramm Elektromobilität (BReg, 2011); available at http:// go.nature.com/2wpad2f (in German).

6. Kemfert, C. CESifo DICE Report 14, 65-70 (2016)

7. BMWi. Bundesbericht Energieforschung 2017 (BMWi, 2017); available at http://go.nature. com/2xv504j (in German).

8. Georgeson, L., Maslin, M. \& Poessinouw, M. Nature 538, 27-29 (2016).

9. Umweltbundesamt. Umweltschädliche Subventionen in Deutschland (UBA, 2016); available at http://go.nature.com/2wajy7v (in German). 